\title{
Investigating State-Level Determinants of Crisis Preparedness in the Egyptian Tourism Sector
}

\author{
Prepared by \\ Prof. Shawky M. Elsubbaugh \\ Professor of Business Administration \\ Business Administration Department \\ Faculty of Commerce, Menoufia University \\ Yasmeen Mohamed Saeed Almaleeh \\ Assistant lecturer at the department of Business \\ Administration, Faculty of Commerce, Menoufia University
}

*Prof. Shawky Mohamed Elsubbaugh, Professor of Business Administration, Head of Business Administration Department, and Dean of the Faculty of Commerce, Menoufia University. His main research interest fields are human resources management, organizational behavior, public administration, and crisis management.

Shawky.elsabagh@commerce.menofia.edu.eg

**Yasmeen Mohamed Saeed Almaleeh, assistant lecturer at the department of Business Administration, Faculty of Commerce, Menoufia University. Her main research interest fields are human resources management, change management, organizational behavior, and crisis management.

Yasmin.mohamed@commerce.menofia.edu.eg 


\begin{abstract}
As vital as it is, tourism is considered as a highly vulnerable industry with so much complexities and interdependencies among its sectors which makes it more prone to crises of all types than other industries. The Egyptian tourism industry is no exception; despite the important role tourism plays in the Egyptian economy, it has been suffering tremendously for the past decade due a series of critical incidents such as political misfortunes, major airline disasters, terrorist attacks, bombings and other crises that made it very difficult to tourism businesses to perform appropriately. In spite of the various reform endeavors taken by the Egyptian formal tourism authorities, the Egyptian tourism industry -based on the views of the research participants- has been lacking the ability to prepare for such crises. Therefore, crisis preparedness was the starting point for this scientific investigation as the main question was: What are the main state-level determinants of crisis preparedness in the Egyptian tourism industry? To answer this question, a hypothesis was developed and tested through the use of structural equation modeling. The final model produced in this scientific investigation could be useful to tourism formal authorities in Egypt as it could help them assess their crisis-preparedness competencies. Therefore, the outcome of the study could be considered as a diagnostic tool for crisis preparedness.
\end{abstract}

Keywords: Crisis preparedness, Crisis readiness, Crisis preparation, Egyptian tourism, Tourism crisis. 


\section{ملخص البحث}

تعد السياحة من المجالات التي تتسم بالهشاشة و التقلب الثديد و ذلك بسبب الدرجة العالية من التشابك والتعقيا والاعتمادية فيما بين قطاعاتها. الأمر الذي يجعلها أكثر عرضة للأزمات بمختلف أنواعها. و لا تعتبر السياحة المصرية استثناءا، على الرغم من الدور المهم الأي تلعبه السياحة في الاقتصاد المصري، فقد عاتت بثدة خلال العقد الماضي بسبب سلسلة من الأحداث الخطيرة مثل الأزمات السياسية والحوادث التي تعرضت لها شركات الطيران الكبرى والهجمات الإرهابية والتفجيرات وغيرها من الأزمات التي جعلت من الصعب جدًا على الكيانات السياحية في مصر أن تقوم بأداء مهامها بشكل لائق. على الرغم من المساعي الإصلاحية المختلفة التي قامت بها هيئات السياحة الرسمية المصرية، فإن صناعة السياحة المصرية ـ بناءً على آراء المشاركين في الاراسة ـ تفتقر إلى القدرة على الاستعداد لمثل هذه الأزمات. لذلك كان الاستعداد للأزمات هو نقطة الانطلاق لهذا البحث العلمي حيث كان السؤال الرئيسي المطروح في هذه الدراسة: ما هي أهم المحددات الرئيسية للاستعداد للأزمات على مستوى الدولة في السياحة المصريةٌ و للإجابة على ذلك السؤال، تم تنمية و اختبار فرض بحثي من خلال النمذجة البنائية. و يعتبر النموذج النهائي الذي تم تطويره من خلا هذا البحث بمثابة أداة تثخيصية للكيانات الرسمية التي تمثل السياحة المصرية و التي سوف تساهم في تحديد تلك الكيانات لقدراتها على الاستعداد للأزمات بمختلف أنواعها. الكلمات المفتاحية: الاستعداد للأزمات، الجاهزية للأزمات، السباحة المصرية، أزمات السياحة. 


\section{Introduction}

Due to the rapidly changing and turbulent world we currently live in, we are becoming more prone to a plethora of crises and disasters. Crises are becoming an inevitable part of businesses and therefore, Crisis management has become a vocal issue in management research. Managers seek in all possible ways to cope with these devastating events that can act as a threat to the very existence of organizations (Faulkner, 2001; Mitroff, 2004; Ritchie, 2004; Coombs, 2018).

As evidenced by decades of research in crisis management, certain industries are more vulnerable to crises than others, due to their nature, the complexity of their regulations and their internal processes. Several researchers agreed that tourism is one of those highly volatile and vulnerable industries (Carlsen \& Liburd, 2008; Maditinos \& Vassiliadis, 2008; Racherla and Hu, 2009; Pennington- Gray et al., 2011; Orchiston, 2013). Volo (2008) argues that any major disruption in tourism can have devastating consequences on the economy of the whole nation. In fact, during the last two decades the tourism industry all over the globe has witnessed an abundance of crises and disasters such as political turbulences, terrorist attacks, economic recession, bio threats, and natural disasters (see https://www.e-unwto.org).

Tourism is considered as one of the fundamental elements of socioeconomic development as it creates job opportunities, enhances world trade, and provides prosperity across the world. In recent years, the tourism industry has contributed about $\$ 2.8$ trillion to the global economy (WTTC, 2019). According to the World Travel \& Tourism Council's (WTTC) global benchmarking report in 2018, the tourism industry contributed about $\$ 8.8$ trillion $(10.4 \%)$ to the global gross domestic 
product (GDP). Figure (1) shows tourism's contribution to global GDP in 2017 and 2018.

Figure (1): Direct and total contribution of tourism to the global economy in 2017 and $2018(\%)$

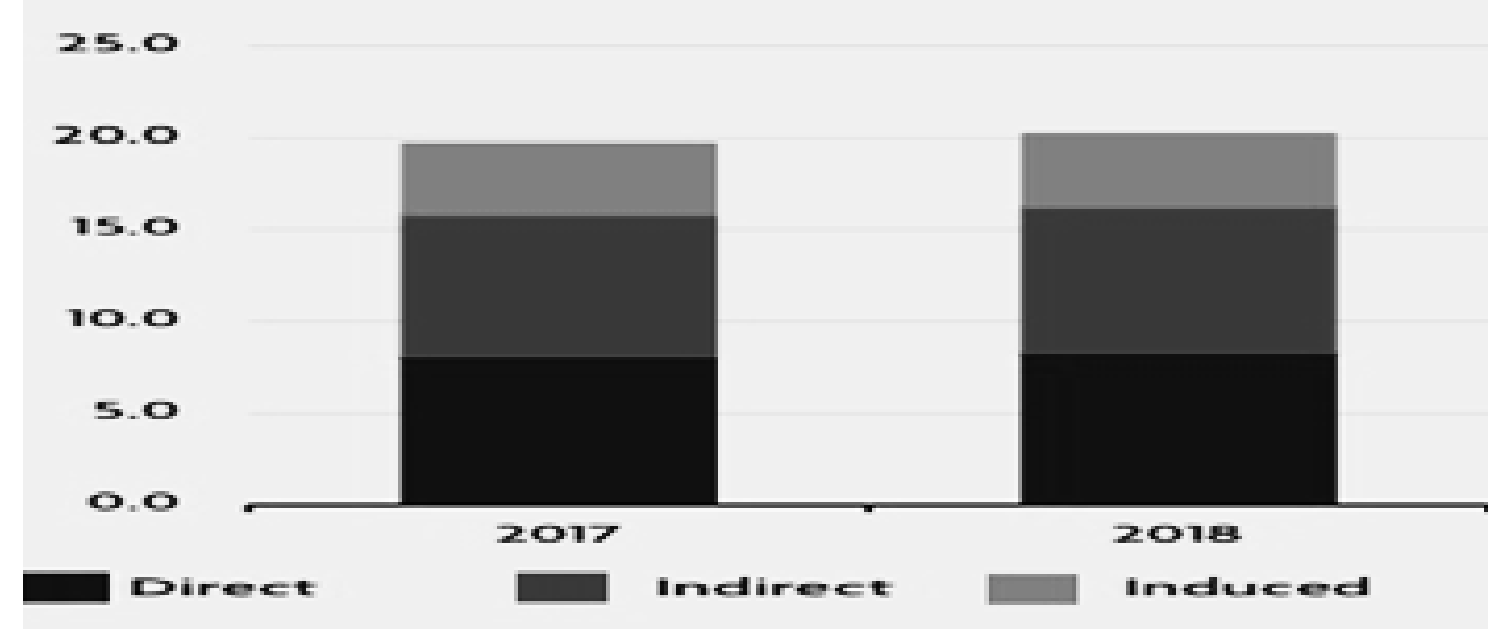

Source: WTTC, 2019

In terms of employment, tourism sustained roughly 319 million jobs around the globe in 2018. Also, tourism was the fastest-growing sector in the world in 2018, expanding by 3.9\% which is more than what the automotive (3.7\%) and health $(3.3 \%)$ industries have achieved (ibid).Paraskevas \& Altinay (2013) stated that tourism is an industry with so much complexities and interdependencies among its sectors which makes it more prone to crises. According to Carlsen \& Liburd (2008), tourism is one of the first sectors to be negatively influenced by disasters and crises. Sönmez et al. (1999) also argued that the periods of time that destinations take to recover from a crisis -regardless of its nature- can have devastating consequences on tourism in terms of the destination's reputation, the conduct of tourism-related activities, and eventually make this area less attractive to tourists. Moreover, tourism crises could cause serious ramifications on the long run which can affect a destination's 
competitiveness because these places can easily be replaced by other destinations that are not affected by the crisis. However, as Maditinos \& Vassiliadis (2008) argue, such negative consequences can be mitigated if stakeholders involved in the tourism industry are well prepared for confronting such incidents. In the same vein, Henderson (2006) emphasizes theimportance of having managers within the tourism industry who are equipped with superior knowledge and skills regarding crisis management in order for them to deal with crisis situations.

Preparing for crises has become a top priority for crisis-management academic research (Kovoor-Misra et al., 2000; Elsubbaugh et al., 2004; Pelfrey, 2005; Fowler et al., 2007; Eriksson, 2015; Coombs, 2018). According to literature, the state of preparedness is perceived in a variety of ways; some thinkers understand preparedness as a group of pre-crisis activities that are deployed to enhance the crisis response (e.g. KovoorMisra et al., 2000; Elsubbaugh et al., 2004). Others argue that crisis preparedness is a stage in the crisis management process during which the organization tries to predict potential crises and project possible solutions (e.g. Coombs, 2018). Sheaffer \& Mano-Negrin (2003) metaphorically described crisis preparedness as a state of organizational mind in which the organization is able to foresee adversary circumstances and proactively prepare for them. Malerova et al. $(2018, \mathrm{p} .8)$ defined crisis preparedness as "the alert status and the capabilities of human, material, and other resources achieved as a result of pre-adopted measures, enabling them to ensure an effective and rapid response to an extraordinary event and a crisis situation with minimization of the consequences".

Research related to tourism crises have generally emphasized the importance of crisis planning (preparedness) in the tourism industry 
(Karagiannis et al., 2006; Wang \& Ritchie, 2010; Ritchie et al., 2011; Pennington-Gray et al., 2011; Wang \& Ritchie, 2013; Orchiston, 2013; Paraskevas \& Altinay, 2013; Martens et al., 2016; Malerova et al., 2018). In their research, Paraskevas \& Altinay (2013) concluded that tourism managers should be able to detect the warning signals that are emitted with a crisis in order to help reduce the organization's exposure to the adverse effects of a crisis.For the last ten years, the Egyptian tourism has been witnessing an abundance of misfortunate events that are caused by economic and political instabilities (Harb, 2013). Consequently, the tourism sector's revenues have declined and the number of tourist arrivals deteriorated (Capmas.gov.eg, 2019). Egypt's image as a tourism destination suffered a considerable damage since then (Gaafar, 2013). Therefore, it could be said that the Egyptian tourism industry was not prepared to handle such events.

\section{Research Purpose}

The purpose of this study is to develop and test a theoretical framework of the major State determinants of crisis preparedness in the Egyptian tourism industry. An exploratory sequential design will be used to first explore qualitatively and then develop an instrument (a survey) that will then be quantitatively tested.

The first phase of the study will be a qualitative exploration of the major crisis-preparedness prerequisites in which data will be collected from executives and business owners registered in the Egyptian Tourism Federation that is divided into five main sectors: hotels, travel agencies, tourist establishments, tourist commodities, and diving and water sports (OECD, 2019) through the use of semi-structured individual in-depth interviews. From this initial exploration, the qualitative findings will be 
used to design a survey research through the use of a questionnaire that can be administered to a larger, statistically-based sample of participants to assess the validity of the developed theoretical framework. Figure (2) illustrates the study procedures.

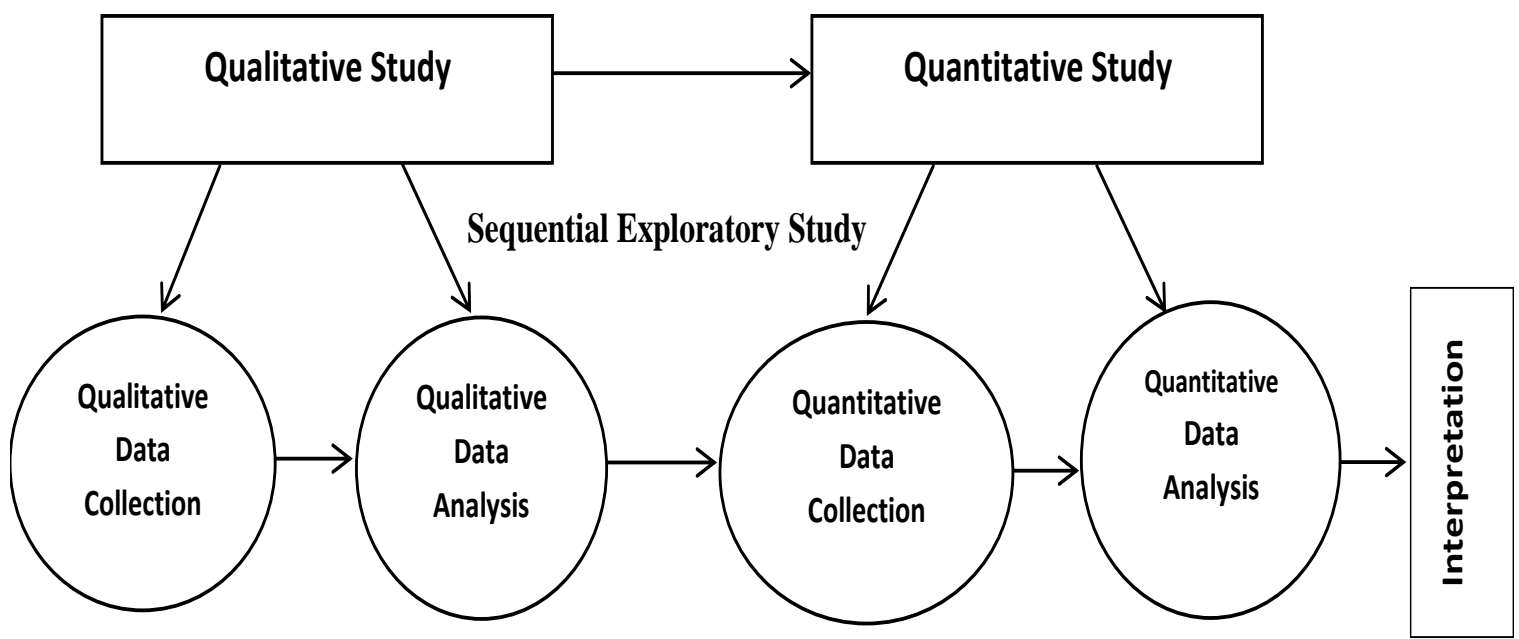

Figure (2): The Study Procedures

Source: Creswell \& Plano Clark (2018)

\section{Research Objectives}

The main objectives of this research are:

- To develop a Theoretical framework of the major determinants of crisis preparedness in the Egyptian tourism industry.

- To assess the levels of representativeness and generalizability those determinants have in the larger research population.

\section{Research Questions}

Qualitative Question: What are the major state determinants of crisis preparedness in the Egyptian tourism industry? 
Quantitative Question: To what extent are the determinants of state crisis preparedness representative of and generalizable to the larger population of Egyptian tourism executives?

\section{Research Contribution}

- The study will establish a theoretical framework that is driven from the analysis of Egyptian tourism executives' opinions and insights, and thus captures the unique features of the research context.

- This Research will provide an important opportunity to advance the understanding of the concept of crisis preparedness especially in tourism industry.

- This research will add to the existing body of knowledge related to tourism crisis management.

- This study will help the official bodies within the tourism industry assess their crisis-preparedness competencies. Therefore, the outcome of the study can be considered as a diagnostic tool for crisis preparedness.

- This study will provide a model that would be more compatible with developing countries such as Egypt.

\section{Literature Review}

\section{6-1 Crisis Defined}

Pauchant \& Mitroff (1992, p.12) define crisis as "a disruption that physically affects a system as a whole and threatens its basic assumptions, its subjective sense of self, and its existential core". Pearson \& Mitroff (1993) argue that crises are events that have the potential to threat the viability of organizations. Coombs (2018, p. 17) agrees with Pauchant \& Mitroff (1992) in the aspect of crisis perceptivity; he defines it as "the perception of an unpredictable event that threatens important expectancies of stakeholders related to health, safety, environmental, and economic issues, and can seriously impact an organization's performance 
and generate negative outcomes". To sum up different perspectives on crisis definition, see table (1).

Table (1): Different perspectives on crisis definition

\begin{tabular}{|c|c|c|}
\hline Definition & Author & Year \\
\hline $\begin{array}{l}\text { A major unpredictable event that has potentially } \\
\text { negative results. The event and its aftermath may } \\
\text { significantly damage an organization and its } \\
\text { employees, products, services, financial } \\
\text { condition, and reputation. }\end{array}$ & Barton & 1993 \\
\hline $\begin{array}{l}\text { An event that can destroy or affect an entire } \\
\text { organization. }\end{array}$ & $\begin{array}{l}\text { Mitroff, Pearson, } \\
\text { \& Harrington }\end{array}$ & 1996 \\
\hline $\begin{array}{l}\text { An organizational crisis is a low-probability, } \\
\text { high-impact event that threatens the viability of } \\
\text { the organization and is characterized by } \\
\text { ambiguity of cause, effect, and means of } \\
\text { resolution, as well as by a belief that decisions } \\
\text { must be made swiftly. }\end{array}$ & Pearson \& Clair & 1998 \\
\hline $\begin{array}{l}\text { A crisis is an undesired, extraordinary, often } \\
\text { unexpected and timely limited process with } \\
\text { ambivalent development possibilities. It demands } \\
\text { immediate decisions and countermeasures in } \\
\text { order to influence the further development again } \\
\text { positively for the organization and to limit the } \\
\text { negative consequences as much as possible. }\end{array}$ & Glaesser & 2006 \\
\hline $\begin{array}{l}\text { A crisis is an event that has a low probability of } \\
\text { occurring, but should it occur, can have a vastly } \\
\text { negative impact on the organization. }\end{array}$ & $\begin{array}{l}\text { Crandall, Parnell } \\
\text { \& Spillan }\end{array}$ & 2014 \\
\hline $\begin{array}{l}\text { the perception of an unpredictable event that } \\
\text { threatens important expectancies of stakeholders } \\
\text { related to health, safety, environmental, and } \\
\text { economic issues, and can seriously impact an } \\
\text { organization's performance and generate } \\
\text { negative outcomes. }\end{array}$ & Coombs & 2018 \\
\hline $\begin{array}{l}\text { A crisis is an event or a situation that can } \\
\text { threaten the survival and goals of an } \\
\text { organization, which creates urgency to resolve it. }\end{array}$ & Kovoor-Misra & 2019 \\
\hline
\end{tabular}

Source: compiled from literature 


\section{6-2 Crisis Preparedness}

During the past twenty years, crisis preparedness has become the core of many crisis-management studies (Kovoor-Misra, 1995, 1996; Elsubbaugh et al., 2004; Pelfrey, 2005; Ritchie et al., 2011; Ritchie et al., 2014; Eriksson, 2015; Malerova et al., 2018; Kovoor-Misra, 2019). The literature is full of different views and perspectives on the concept of crisis preparedness, and therefore, in table (2), the researcher aims to compare and contrast a number of those views and also highlight three key points:

Firstly, most of the existing body of literature on crisis preparedness has been conducted in developed countries such as USA, North Holland, Australia, Sweden, and Israel. Secondly, the majority of studies on crisis preparedness have been carried out through the sole use of either

qualitative or quantitative research methods as almost none of the existing research utilized mixed methods research designs. And thirdly, the time sequence of these studies implies that crisis preparedness can be considered as an intriguing topic for even more research.

One group of scholars understands crisis preparedness as an ongoing "independent" process that aims to develop the organization's competencies to respond to crisis (Kovoor-Misra, 1995; Eriksson, 2015; Malerova et al., 2018). While other thinkers see it as a bundle of activities and procedures that represent the pre-crisis stage in a crisis-management process, these activities aim to enhance the organization's readiness for potential crises (Ritchie et al., 2011; Pennington-Gray et al., 2011; Heiselt \& Burrell, 2012). 
Table (2): A comparison among different views on the concept of crisis preparedness in the existing literature

\begin{tabular}{|c|c|c|}
\hline Author & Year & Crisis Preparedness/Readiness/Planning defined as: \\
\hline $\begin{array}{l}\text { Kovoor- } \\
\text { Misra }\end{array}$ & 1996 & $\begin{array}{l}\text { A crisis prepared organization is defined as one that } \\
\text { has the capability to prevent, contain, recover, and } \\
\text { learn from a range of crises in all its dimensions and } \\
\text { layers. }\end{array}$ \\
\hline $\begin{array}{l}\text { Kovoor- } \\
\text { Misra }\end{array}$ & 1995 & $\begin{array}{l}\text { An ongoing process of developing organizational } \\
\text { capabilities in order to prevent, contain, and recover } \\
\text { from crises, and learn from experience. }\end{array}$ \\
\hline $\begin{array}{l}\text { Sheaffer \& } \\
\text { Mano- } \\
\text { Negrin }\end{array}$ & 2003 & $\begin{array}{l}\text { A state of corporate readiness to foresee and effectively } \\
\text { address internal and external adversary circumstances } \\
\text { with the potential to inflict a multidimensional crisis, by } \\
\text { consciously recognizing and proactively preparing for its } \\
\text { inevitable occurrence. }\end{array}$ \\
\hline Pelfrey & 2005 & $\begin{array}{l}\text { A term which implies that the required plans, policies, } \\
\text { materials, and trainings are available to manage and } \\
\text { limit the catastrophic effects of major crises. }\end{array}$ \\
\hline $\begin{array}{l}\text { Ritchie et } \\
\text { al. }\end{array}$ & 2011 & $\begin{array}{l}\text { All the actions taken in the first and proactive stage of } \\
\text { crisis management, including the creation of crisis } \\
\text { teams, as well as a crisis training and simulation } \\
\text { exercises. }\end{array}$ \\
\hline $\begin{array}{l}\text { Pennington- } \\
\text { Gray } \\
\text { Et al }\end{array}$ & 2011 & $\begin{array}{l}\text { The activities and procedures that are necessary to } \\
\text { evaluate the level of organizational readiness for a } \\
\text { potential crisis and the development of strategic, } \\
\text { tactical communication plans to manage a potential } \\
\text { crisis. }\end{array}$ \\
\hline $\begin{array}{l}\text { Heiselt \& } \\
\text { Burrell }\end{array}$ & 2012 & $\begin{array}{l}\text { The aspect of crisis management that focuses on the } \\
\text { preparation that occurs before a crisis incident, and } \\
\text { how learning from these experiences can prevent } \\
\text { future crisis. }\end{array}$ \\
\hline Eriksson & 2015 & $\begin{array}{l}\text { A continuous process aiming to enhance the } \\
\text { organization's ability to respond to crisis (a learning } \\
\text { process) }\end{array}$ \\
\hline $\begin{array}{l}\text { Malerova et } \\
\text { al. }\end{array}$ & 2018 & $\begin{array}{l}\text { The alert status and the capabilities of human, } \\
\text { material, and other resources achieved as a result of } \\
\text { pre-adopted measures, enabling them to insure an } \\
\text { effective and rapid response to an extraordinary event } \\
\text { and a crisis situation with minimization of } \\
\text { consequences. }\end{array}$ \\
\hline
\end{tabular}

Source: compiled from literature 


\section{6-3 Egyptian Tourism (Research Context)}

Egypt has many tourism attraction elements that draw people from all around the world; cultural, recreational, spiritual, sports, therapeutic, and above all, historical tourism all made Egypt one of the most attractive world destinations (www.Egypt.travel, 2019).The tourism Industry plays a substantial role in the Egyptian economy; According to the latest country report provided by WTTC on the Egyptian tourism economic impact in 2018 (Turner, 2018), Tourism's total contribution to Egypt's GDP in 2017 was up to $11.9 \%$ and was forecasted to rise to $16.5 \%$ by the end of 2018 . Also, key economic descriptive elements show the magnitude of tourism; in 2015 tourism provided up to $12 \%$ of foreign currency, $34 \%$ of total export services, $19 \%$ of direct taxes on services, $4.5 \%$ of direct sales tax, and 6.6\% of total employment (Capmas.gov.eg, 2019).In addition, Egypt is considered to have high price competitiveness as it ranks the $4^{\text {th }}$ destination with low costs (Turner, 2018). This implies low prices compared to other destinations- of plane tickets, hotel nights, internal transportations...etc.

The Egyptian ministry of tourism represents the formal entity that is responsible for state policies regarding tourism (Ministry of Tourism, 2018). The main function of the ministry is to regulate and facilitate tourism activities and work with other governmental and private businesses to organize the tourism industry (ibid).

The Egyptian tourism overall authorities are represented by two main governmental bodies and five chambers -see figure (3)-. The two bodies which are directly under the jurisdiction of the tourism ministry are the Egyptian Tourism Authority (ETA) and the Tourism Development Authority (TDA). Among the main tasks of TDA are to formulate and supervise the execution of development plans in tourist regions, implement 
infrastructure projects in tourist regions with payment of services and utilities costs, and Manage and exploit desert lands to establish tourist regions (www.tda.gov.eg, 2019).

Figure (3): Major Egyptian Tourism Bodies

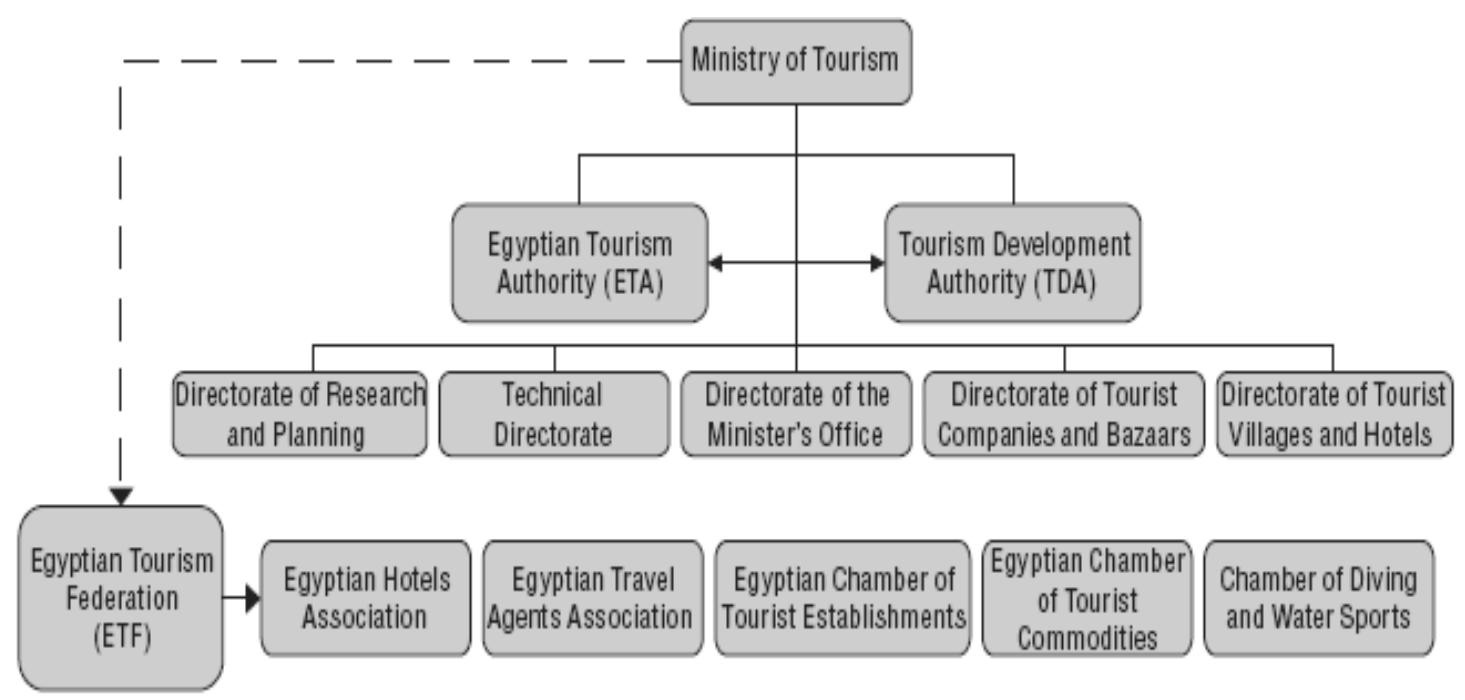

Source: Ministry of Tourism, 2018

Over the last decade, Egypt's tourism industry has suffered a series of critical incidents such as political misfortunes, major airline disasters, terrorist attacks, and bombings (WTTC, 2018; World Bank, 2018). The following discussion presents historical data about the Egyptian tourism from year 2010 up to the latest reports provided by a variety of organizations such as: The World Travel \& Tourism Council (WTTC, 2018), the World Bank (World Bank, 2019), the World Economic Forum (weforum.org, 2019), the Central Bank of Egypt (cbe.org.eg, 2019), and the Central Agency for Public Mobilization \& Statistics (Capmas.gov.eg, 2019).

Year 2010 was the year prior to the beginning of political turbulence and the fall of the political regime. Statistical indicators of 2010 showed a highperformance tourism industry comparing to previous years; tourism's 
total contribution to GDP reached $7.8 \%$, the number of tourist arrivals was $14,731,000$ tourists, and tourist nights were $147,385,000$ nights.

Year 2011 was the year when the Arab Spring and the overthrow of the political regime took place. This political turbulence lead to a decline in tourist arrivals by nearly a third; tourism's total contribution to GDP fell

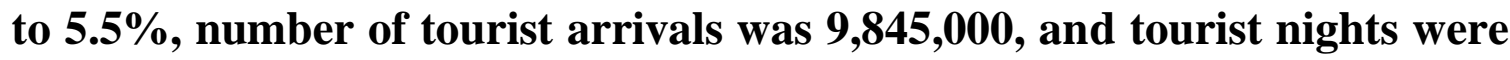
114,214,000 nights. According to the travel and tourism competitiveness report in 2011, Egypt ranked the $75^{\text {th }}$ out of 140 countries in tourism attraction.

Year 2013 was when history repeated itself. Political turbulence lead to the ousting of the political regime again which, in turn, lead to a major decline in tourist arrivals to reach $9,464,000$ tourists, tourism's contribution to GDP declined to $4 \%$, and tourist nights were $\mathbf{9 , 4 4 1 , 0 0 0}$ nights. Egypt ranked the $85^{\text {th }}$ out of 140 countries in tourism attraction.

Years 2014, 2015 and 2016, major devastating incidents happened during those years such as; the bombing at the museum of Islamic Art which forced it to close up to two years, the downing of a Russian airliner (Airbus A321) over Sinai killing 224 people mostly tourists which lead to Russia putting an indefinite ban on all travel to Egypt, a number of European governments and airline corporations placed flight restrictions and warned their citizens of traveling to Egypt over security concerns, terrorist attacks in Hurghada, gunmen opening fire on a tourist bus in Cairo, and deadly attacks on churches in Alexandria and Tanta. All those tragic events lead to a drastic decline in tourists' demand to Egypt; the number of tourist arrivals went from 14.7 million in 2010 to 9.8 million in 2014 to eventually fall to 5.4 million in $\mathbf{2 0 1 6}$, tourism's contribution to GDP deteriorated to reach $3.2 \%$. 
Figure (4): Tourists Arrivals in Egypt from 2010 to 2016(in millions)

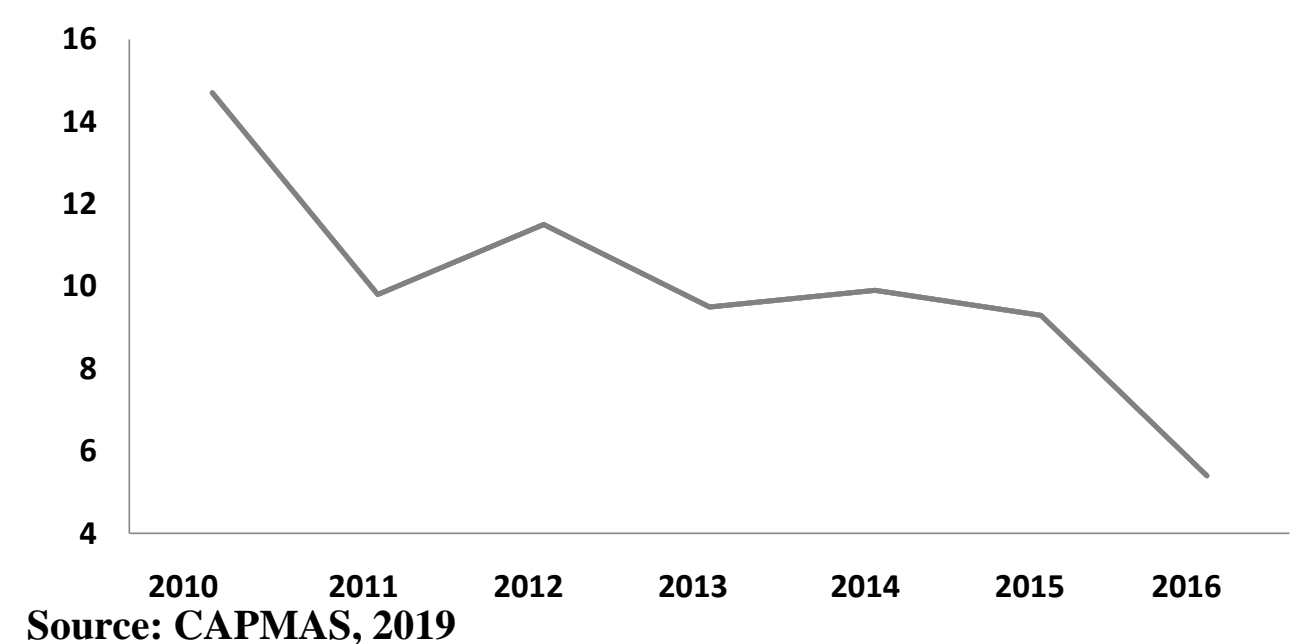

By examining figure (4), it can be argued that the period between 2011 and 2016 was a crisis time to the Egyptian tourism, where different indicators of industry performance have shown a drastic decline if compared to the period prior to 2010.

Years 2017 until the present time, those years witnessed an improvement in the performance of tourism industry as political conditions somewhat settled and many endeavours were taken to repair the country's image and recover the losses that occurred due to the drastic fall of tourists' arrivals (Oxford Business Group, 2019) This upward momentum was manifested in an increased number of tourist arrivals which increased to 8.3 million in 2017 and reached 11.3 million in 2018 (Capmas.gov.eg, 2019).

The tourism industry's return has been partially the product of the depreciation of the Egyptian pound, which has made the country a cheaper and more price-competitive destination for a large number of tourists (Oxford Business Group, 2019). Also, there has been a great focus on security issues to regain the trust of countries that once considered Egypt as a troubled area, for example, the authorities managed to meet all 
the criteria imposed by the Russian government to resume flights to the country, following the downing of a Russian plane over Sinai in October 2015. This included new security measures at the country's international airports (Reuters.com, 2019). All those efforts provided a great boost for the industry.

Adding to this, the Egyptian-tourism reform program that was launched from Parliament on November 27, 2018 and endorsed by the government was an important step toward setting a clear vision and key goals to the Egyptian tourism industry (www.Egypt.travel, 2019). The reform program was based entirely on the 2030 agenda for sustainable development provided by the UNITED NATIONS (Sustainabledevelopment.un.org, 2019). The structural reform pillars were: institutional, legislative, branding \& promotion, infrastructure \& tourism development, and international tourism trends. The main purpose of the reform program was to put Egypt on a sustainable path, consistent with the United Nations Sustainable Development Goals. According to the Daily news Egypt (2019) the first monitoring report of the reform program is not yet published in order to stand on its results. However, the researcher was highly concerned to find within the folds of this reform program any sign of a crisis-preparation strategy or scenarios that tourism organizations should follow if a threat of any kind should attack them. Also, another critical issue was to investigate from the participants of this current research whether they were involved, consulted, or even informed of such endeavour.

\section{Methodology}

\section{7-1 Population}

This research population consists of all executives representing the Egyptian Tourism Federation which is divided into five main sectors: 
hotels, travel agencies, tourist establishments, tourist commodities, and diving and water sports (OECD, 2019). The choice of research population is justified by the rationale that ETF works closely with the Ministry of Tourism in areas related to tourism planning, and for managing the tourism workforce skills development. By law, ETF's views are considered before any new legislative measures are to be imposed (Ministry of tourism, 2018).

\section{7-2 Qualitative Data Collection, Analysis, and Results (Phase 1)}

The goal of this phase is to identify the major determinants of state crisis preparedness in the Egyptian tourism industry.At the beginning of the study, purposeful sampling was adopted which implies that the researcher intentionally recruited participants who have a considerable field experience concerning the concepts being explored (Creswell \& Poth, 2018). After a number of preliminary interviews, snowballing technique was employed as the participants who were already interviewed recommended the rest of the individuals who were later recruited for the study.

The first interview was conducted with a travel agency owner located in Cairo with more than twenty-eight years of experience in the field of tourism in general and about fifteen years being a travel agent. The second interview was with a diving center owner in Dahab who was also very experienced and had witnessed a lot of tourism crises since 1991. Those first two participants recommended the third (travel agent), fourth (restaurant owner) and fifth (hotel manager) participants.

The rest of the interviews were based on the same sampling technique. By conducting interviews with participants in all five branches of the Egyptian tourism industry and also putting into consideration their geographical dispersion, the researcher aimed to gain a better, deeper, and 
more comprehensive understanding of how the participants would agree or differ in their responses to the interview discussion points, this sampling strategy -according to Creswell \& Plano Clark (2018)- is called maximal variation sampling in which diverse participants are intentionally chosen because they are expected to possess different perspectives on the research phenomenon.

By the end of data collection of phase (1), a total of 33 participants were interviewed using individual in-depth semi-structured interview method in which the interviewer (the researcher) tried to evoke a number of discussion points, these points can be summarized as follows:

- The current and potential problems facing Egyptian tourism

- A description of the concept of "being ready" to face tourism problems

- Sources of tourism problems

- Suggestions of solutions to solve tourism problems

As for the coding process, the researcher followed the guidelines of Charmaz (2006) and Creswell \& Poth (2018). The process started with reviewing the transcribed interviews with an attempt to give labels to the views and opinions of the participants.

The interviews were conducted in Arabic because it's the mother language of all participants. Therefore, the codes were also phrased in Arabic at this stage. Through the initial Memoing, the researcher realized that the best way to get answers that are relevant and realistic was to ask questions indirectly; instead of asking about those determinants or perquisites, the participants were given maximum freedom in telling why they believe the performance the Egyptian tourism industry has diminished over the past ten years. Also, they were allowed to express their opinions on what to do or what would it take to be better prepared in the future. Therefore, the 
answers came out as "perceived problems" or "obstacles" which were later coded as determinants or perquisites. This stage produced 19 codes. Table (3) shows some examples of how codes were generated.

Table (3): Examples of open codes (translated from Arabic)

\begin{tabular}{|l|l|}
\hline Code & Examples \\
\hline \multirow{3}{*}{$\begin{array}{l}\text { Market } \\
\text { Diversity }\end{array}$} & "the real problem is that we are not diversified" \\
\cline { 2 - 2 } & "we don't have alternative markets" \\
\cline { 2 - 2 } $\begin{array}{l}\text { "It all happened when the Russian plane went down } \\
\text { because we depend mainly on the Russian tourist" }\end{array}$ \\
\hline $\begin{array}{l}\text { Strategic } \\
\text { Planning }\end{array}$ & $\begin{array}{l}\text { "there is no institutional role or a clear vision for the } \\
\text { country" }\end{array}$ \\
\cline { 2 - 2 } $\begin{array}{l}\text { "the government is not involved in our problems, we } \\
\text { are on our own" }\end{array}$ \\
\hline \multirow{3}{*}{$\begin{array}{l}\text { Communication } \\
\text { State-level }\end{array}$} & $\begin{array}{l}\text { No, unfortunately I know nothing about the minister's } \\
\text { endeavor }\end{array}$ \\
\cline { 2 - 2 } Habilitation & $\begin{array}{l}\text { "the state is not really concerned with habilitating } \\
\text { those who work directly with tourists" }\end{array}$ \\
\cline { 2 - 2 } & $\begin{array}{l}\text { "why wouldn't the government give training courses to } \\
\text { police officers, for example, who interact directly with } \\
\text { foreigners?!" }\end{array}$ \\
\hline
\end{tabular}

Source: The Researcher

After the coding, the researcher carefully examined the relationship between the 19 codes and realized that the produced codes can be aggregated into one main theme; Determinants of state-level tourism crisis preparedness. Table (4) shows the developed theme and its corresponding codes.

Table (4): the developed theme and its corresponding codes.

\begin{tabular}{|l|l|}
\hline Category (theme) & Codes \\
\hline \multirow{4}{*}{$\begin{array}{l}\text { State-Level } \\
\text { Determinants }\end{array}$} & State's Tourism-Crisis Planning \\
\hline & State of National Security \\
\cline { 2 - 2 } & National Culture \\
\cline { 2 - 2 } & State-level Communication \\
\hline & State-level Habilitation \\
\hline & Infrastructure \\
\hline
\end{tabular}

Source: The researcher 
1) State's Tourism Crisis Planning

The first code that emerged from the data regarding the determinants of tourism crisis preparedness was 'State's Tourism Crisis Planning'. This concept refers to the decisions and activities undertaken by national tourism authorities to assist stakeholders in developing readiness strategies, conserve a welcoming image of the country, and develop a comprehensive crisis plan for tourism.

Many participants praised the current endeavors undertaken by the Egyptian presidency to restore the country's image and encourage global tourism to visit/revisit Egypt. However, they expressed that the problem is that those endeavors should be tied to a cohesive tourism strategic plan that has all stakeholders involved in its development and implementation.

\section{2) State of National Security}

One code that was relatively easily generated during qualitative data analysis and had noticeably no equivalent in the two other levels of the theoretical model was the one titled 'State of National Security'. Almost all participants agreed that in order for tourism to thrive and regain strength, national security must be assured. One participant (a Bazar owner in Dahab) said "I'm ok with the big number of searching points that each vehicle has to go through when driving to Dahab because only then would I and everyone else feel really safe and secured". On the other hand, one participant argued "reflecting too much security may work as bad as too little! A country that comes out as a military barrack may discourage tourists to visit it".

\section{3) National Culture}

Another code that was present in the interviews was 'National Culture' which implies that in order for a nation to prepare itself against tourism crises and disasters, it must possess a strong and sustaining national culture that is based on respect and appreciation for tourists. People must acknowledge and respect the differences in norms and traditions between 
them and those foreigners who may be visiting the country for the first time and whose word of mouth could encourage/discourage others to visit the country.

\section{4) State-level Communication}

The 'communication' code came as a byproduct when participants were talking about the state's strategic planning; they addressed that many endeavors are indeed taken. However, these endeavors are not communicated to them as tourism stakeholders. They feel oblivious and outcast from the country's efforts to restore the tourism industry. Another pattern in the interviews that produced this code was when the participants shed the light on the role of public media in times of crises. One participant argued that sometimes a minor incident in one remote area can get exaggerated to become a serious cause of loss in tourists' numbers.

\section{5) State-level Habilitation}

This code emerged as a byproduct from the participants' comments on how the current culture of the people does not reinforce tourism. One participant said that the government as a whole is not interested in habilitating those who work in touristic areas like policemen and other administrative positions so that they can better interact with foreign tourists. Another participant said "If I was in charge, I wouldn't give permissions to anyone to work in governmental entities knowing that he/she might interact with a tourist, unless I make sure that this person is qualified -in terms of language and knowledge- to do so".

6) Infrastructure

Another code that was rather easy to emerge is 'infrastructure'. Participants unanimously agreed that high crisis preparedness in tourism is conditioned to solid infrastructure. One participant said "tourism requires very good roads". Another one argued "how could we expect 
high readiness with this outdated telecommunication network! A simple telephone call can take forever to make!".

\section{7-3 Instrument Development (Interim Phase)}

This exploratory-sequential mixed-methods research is conducted mainly to develop and test a theoretical framework. The testing procedure is to be accomplished through the development an instrument (a survey) that is quantitatively tested (see Creswell \& Plano Clark, 2018). For this study, the instrument is a questionnaire that measures the degree to which the developed determinants reflect the latent variables According to DeVellis (2017), scale development is a rigorous process that should follow a number of guidelines (see DeVellis, 2017 p. 36). After the development of the questionnaire items, the next step is to have a group of people who have considerable knowledge and experience in survey development and questionnaire building. These experts were asked if the generated items reflected what the researcher intended to measure. This procedure was carried out through listing on a paper the questionnaire items on one side and the constructs (latent variables) on the opposite side, each expert, then, was asked to link between the items and the constructs based on how much he/she thought the former express the latter.

Reviewers were also asked to evaluate the items' wording clarity and precision. The researcher asked them to point out awkward or confusing items that could imply confusing meanings and suggest alternative wordings for them. Lastly, the reviewers were asked to propose other ways of tackling the phenomenon that the researcher may have failed to include. For example, for the initial group of items that should reflect sector's marketing diversity, one expert (a fellow university lecturer) proposed that it would be better to describe 'marketing diversity' through the components of the marketing mix (4 Ps). The researcher put that into consideration and modified the wording of statements accordingly. 


\section{7-4 Testing Model Validity \& Reliability, (Phase 3)}

This phase is designed to answer this research question:

- To what extent can the level of tourism state-level crisis preparedness be assessed based on the previously-described determinants?

This question lead to the following research hypothesis:

H: Egyptian state-level tourism crisis preparedness is a multileveled construct composed of a number of determinants; state crisis planning, communication, habilitation, national culture, national security, and infrastructure.

The researcher applied Israel's (1992) table to calculate the sample size for the quantitative survey. This table provides a $95 \%$ confidence interval and a precision level of $\pm 5 \%$ (see table 5). Based on a total population of 7,608 units, the researcher determined the sample size should minimally be 381 units. This sample was divided into quotas based on the percent of each chamber's members in the population which implies that the study sample represented the five chambers in the same percentages that exist in the population.

Table (5): Sample size for $\pm 3 \%, \pm 5 \%, \pm 7 \%$ and $\pm 10 \%$ Precision Levels Where Confidence Level is $95 \%$

\begin{tabular}{|l|l|l|l|l|}
\hline \multirow{2}{*}{$\begin{array}{l}\text { Size of } \\
\text { Population }\end{array}$} & \multicolumn{4}{|c|}{ Sample Size (n) for precision (e) of: } \\
\cline { 2 - 5 } & $\mathbf{\pm 3 \%}$ & $\mathbf{4 5 \%}$ & $\mathbf{+ 7 \%}$ & $\mathbf{\pm 1 0 \%}$ \\
\hline $\mathbf{3 , 0 0 0}$ & $\mathbf{8 1 1}$ & $\mathbf{3 5 3}$ & $\mathbf{1 9 1}$ & $\mathbf{9 7}$ \\
\hline $\mathbf{4 , 0 0 0}$ & $\mathbf{8 7 0}$ & $\mathbf{3 6 4}$ & $\mathbf{1 9 4}$ & $\mathbf{9 8}$ \\
\hline $\mathbf{5 , 0 0 0}$ & $\mathbf{9 0 9}$ & $\mathbf{3 7 0}$ & $\mathbf{1 9 6}$ & $\mathbf{9 8}$ \\
\hline $\mathbf{6 , 0 0 0}$ & $\mathbf{9 3 8}$ & $\mathbf{3 7 5}$ & $\mathbf{1 9 7}$ & $\mathbf{9 8}$ \\
\hline $\mathbf{7 , 0 0 0}$ & $\mathbf{9 5 9}$ & $\mathbf{3 7 8}$ & $\mathbf{1 9 8}$ & $\mathbf{9 9}$ \\
\hline $\mathbf{8 , 0 0 0}$ & $\mathbf{9 7 6}$ & $\mathbf{3 8 1}$ & $\mathbf{1 9 9}$ & $\mathbf{9 9}$ \\
\hline
\end{tabular}

Source: Israel (1992) 
Exploratory Factor Analysis (EFA)

EFA was conducted on all constructs through the use of IBM-SPSS 23.0 with principal component as the extraction method. Initially, the factorability of the produced constructs was examined. A number of wellknown criteria for the items factorability were used. First, the correlation matrix of the items should be examined; items that are presumed to measure the same underlying construct are normally expected to have high correlation (above 0.3) (Hair, 2014; Field, 2018). However, items with correlations of more than .9 represent a problem of multicollinearity, therefore, its advised to eliminate one of the two items. Second, KiserMeyer-Olkin (KMO) and Bartlett's test of Sphericity are used to measure sampling adequacy. The KMO is acceptable if its 0.6 or above (Awang, 2012) and Bartlett's test of Sphericity should be significant $(p<0.05)$ in order for the factor analysis to be appropriate (Hair, 2014). Third, Total Variance Explained (TVE) is examined to reduce the measuring items into a less number of factors. During this procedure, items with eigenvalues that exceed 1.0 are extracted to different components (Field, 2018). Forth, the pattern matrix is employed to decide which items to stay and which to leave the analysis. In the pattern matrix, only items with a factor loading that equals to or more than $\mathbf{0 . 6}$ are advised to be retained for further analysis (Awang, 2012).

To initiate EFA, the researcher firstly performed a correlation analysis on all parts of the questionnaire separately to make sure that most of the items in the same category correlate with each other at least at 0.3. From this initial examination, it was noticed that item (sti2) which denotes public transportation's quality had a correlation of less than .3 with the rest of the items that measure the construct (state infrastructure quality). Therefore, it was decided to eliminate this item. Secondly, KMO \& 
Bartlett's test was conducted to measure sampling adequacy. Table (6) represents its results.

Table (6): KMO \& Bartlett's tests for State-level crisis preparedness

\begin{tabular}{|c|c|c|c|}
\hline Construct & \multicolumn{3}{|c|}{ KMO and Bartlett's Test } \\
\hline \multirow{4}{*}{$\begin{array}{c}\text { State-Level } \\
\text { Preparedness }\end{array}$} & \multicolumn{2}{|c|}{$\begin{array}{c}\text { Kaiser-Meyer-Olkin Measure of Sampling } \\
\text { Adequacy. }\end{array}$} & $\mathbf{. 8 6 4}$ \\
\cline { 2 - 4 } & $\begin{array}{c}\text { Bartlett's Test of } \\
\text { Sphericity }\end{array}$ & $\begin{array}{c}\text { Approx. Chi- } \\
\text { Square }\end{array}$ & $\mathbf{2 3 6 9 . 1 8 0}$ \\
\cline { 2 - 3 } & & Df & 190 \\
\cline { 2 - 3 } & & Sig. & $\mathbf{. 0 0 0}$ \\
\hline
\end{tabular}

Source: SPSS output

As the table depicts, the construct had a KMO of more than .6 , and Bartlett's test revealed a $p<0.05$. Therefore, KMO of .6 or more and Bartlett's test significant value suggest that the data set is adequate for further analysis (Awang, 2012; Hair, 2014; Field, 2018).

Total Variance Explained (TVE) was conducted as an extraction process to reduce the items into manageable number of constructs (factors). In the procedure, the researcher chose to extract the items based on eigenvalues more than 1.0.Table (7) represents the TVE for the developed construct.

Table (7): The Total Variance Explained for (State-Level Crisis Preparedness) Construct

\begin{tabular}{|c|c|c|c|c|c|c|c|}
\hline \multirow{2}{*}{$\begin{array}{c}\text { Compon } \\
\text { ent }\end{array}$} & \multicolumn{3}{|c|}{ Initial Eigenvalues } & \multicolumn{3}{|c|}{$\begin{array}{l}\text { Extraction Sums of } \\
\text { Squared Loadings }\end{array}$} & \multirow{2}{*}{$\begin{array}{c}\begin{array}{c}\text { Rotation } \\
\text { Sums of } \\
\text { Squared } \\
\text { Loadings }\end{array} \\
\text { Total }\end{array}$} \\
\hline & Total & \begin{tabular}{|c}
$\%$ of \\
Varianc \\
e
\end{tabular} & $\begin{array}{l}\text { Cumulati } \\
\text { ve \% }\end{array}$ & Total & $\begin{array}{c}\% \text { of } \\
\text { Varianc } \\
\text { e }\end{array}$ & $\begin{array}{c}\text { Cumulat } \\
\text { ive } \%\end{array}$ & \\
\hline 1 & 6.782 & \begin{tabular}{|l|l|}
33.908 \\
\end{tabular} & 33.908 & 6.782 & 33.908 & 33.908 & 5.171 \\
\hline 2 & 2.576 & 12.881 & 46.789 & 2.576 & 12.881 & 46.789 & 4.206 \\
\hline 3 & 1.709 & 8.543 & $\mathbf{5 5 . 3 3 2}$ & 1.709 & 8.543 & 55.332 & 3.945 \\
\hline 4 & 1.354 & 6.771 & 62.103 & 1.354 & 6.771 & 62.103 & 3.987 \\
\hline 5 & 1.239 & 6.194 & 68.297 & 1.239 & 6.194 & 68.297 & 3.314 \\
\hline 6 & 1.061 & 5.305 & 73.602 & 1.061 & 5.305 & 73.602 & 2.240 \\
\hline
\end{tabular}

Source: SPSS output 
As it can be seen in table (7), the EFA for the (State-Level Crisis Preparedness) Construct extracted 6 factors with 6.8 for factor 1, 2.6 for factor $2,1.7$ for factor $3,1.4$ for factor $4,1.2$ for factor 5 , and 1.06 for factor 6. This means that the items are reduced to six distinct groups of factors. The table also shows that TVE for the (State-Level Crisis Preparedness) Construct is $\mathbf{7 3 . 6 \%}$.

Since the original theoretical model considered six factors to represent state-level crisis preparedness, also the initial correlation analysis lead to the elimination of (sti2) item, it was decided that the extracted components are adequate for further analysis.

Table (8): the pattern matrix for (State-Level Crisis Preparedness) Construct

\begin{tabular}{|c|c|c|c|c|c|c|}
\hline \multirow{2}{*}{$\begin{array}{l}\text { Item } \\
\text { code }\end{array}$} & \multicolumn{6}{|c|}{ Component } \\
\hline & 1 & 2 & 3 & 4 & 5 & 6 \\
\hline Stp1 & & & & .841 & & \\
\hline Stp2 & & & & .909 & & \\
\hline Stp3 & & & & .723 & & \\
\hline Stm1 & & & & & & .833 \\
\hline Stm2 & & & & & & .855 \\
\hline Sth1 & & .810 & & & & \\
\hline Sth2 & & .911 & & & & \\
\hline Sth3 & & .955 & & & & \\
\hline Sth4 & & .886 & & & & \\
\hline Sts1 & & & & & .802 & \\
\hline Sts2 & & & & & .932 & \\
\hline Sti1 & .820 & & & & & \\
\hline Sti2 & .925 & & & & & \\
\hline Sti3 & .879 & & & & & \\
\hline Sti4 & .923 & & & & & \\
\hline Sti5 & .577 & & .313 & & & \\
\hline Stc1 & & & .805 & & & \\
\hline Stc2 & & & .620 & & & \\
\hline Stc3 & & & .580 & & .336 & \\
\hline Stc4 & & & .957 & & $-.300-$ & \\
\hline
\end{tabular}

Source: SPSS output 
The results in table (8) indicate that the EFA for (State-Level Crisis Preparedness) Construct extracted 6 components. Each component has a specific number of items with their respective factor loadings. In the research at hand and based on the work of Awang (2012), only items that have a factor loading of $\mathbf{0 . 6}$ or more on a particular factor will be retained as it indicates the adequacy of items in measuring the construct. For example, item (sti5) loaded on two factors (1 and 3). However, the researcher decided to retain the item on the factor it loaded more on (factor 1). The same could be said on items (stc3 and stc4). As a result, all 19 items will be retained and considered for further analysis.

Testing the Measurement Model (The Confirmatory Factor Model)

The confirmatory factor model specifies the relationships among the observed variables and their underlying latent variables. Confirmatory factor analysis is conducted to establish a strong measurement model out of the theoretical model of research phase (1).

\section{Specification}

Figure (4) depicts the 1st and 2nd order confirmatory factor models of 19 observed variables with 6 distinct latent constructs that are hypothesized to measure state-level tourism crisis preparedness (latent construct n.7). In this model, each observed variable is hypothesized to measure only a single latent factor. In addition, the measurement error variances were not hypothesized to be related.

\section{Identification}

To assess the level of identification, the order condition was identified. Under the order condition, the number of free parameters to be estimated must be less than or equal to the number of distinct values in the sample covariance matrix S. (Schumacker \& Lomax, 2004). As shown in Table (9), the order condition stated that the number of distinct values in the matrix $\mathrm{S}$ was $\mathbf{1 9 0 ,}$, while there was a total of 53 free parameters to be estimated. 
Table (9): Order Condition of the State-Level-Crisis-Preparedness Confirmatory Factor Model

\begin{tabular}{|c|l|}
\hline Number of distinctValues in $S$ & Number of free parameters to be estimated \\
\hline & 19 factor loadings \\
$P(P+1) / 2$ & 19 measurement error variances \\
$19(19+20) / 2$ & 0 measurement error covariance or \\
& correlations \\
& 15 correlations among the latent variables \\
\hline 190 & \multicolumn{1}{|c|}{53} \\
\hline
\end{tabular}

Based upon the order condition, this model is over-identified, since the number of distinct values in $S$ is 190 is greater than the number of free parameters which is 53. Accordingly, the degrees of freedom are positive

$$
d f=190-53=137
$$

Thus, this model was concluded as over-identified.

Figure (4): $1^{\text {st }}$ and $2^{\text {nd }}$ order Confirmatory factor models of state-level crisis preparedness
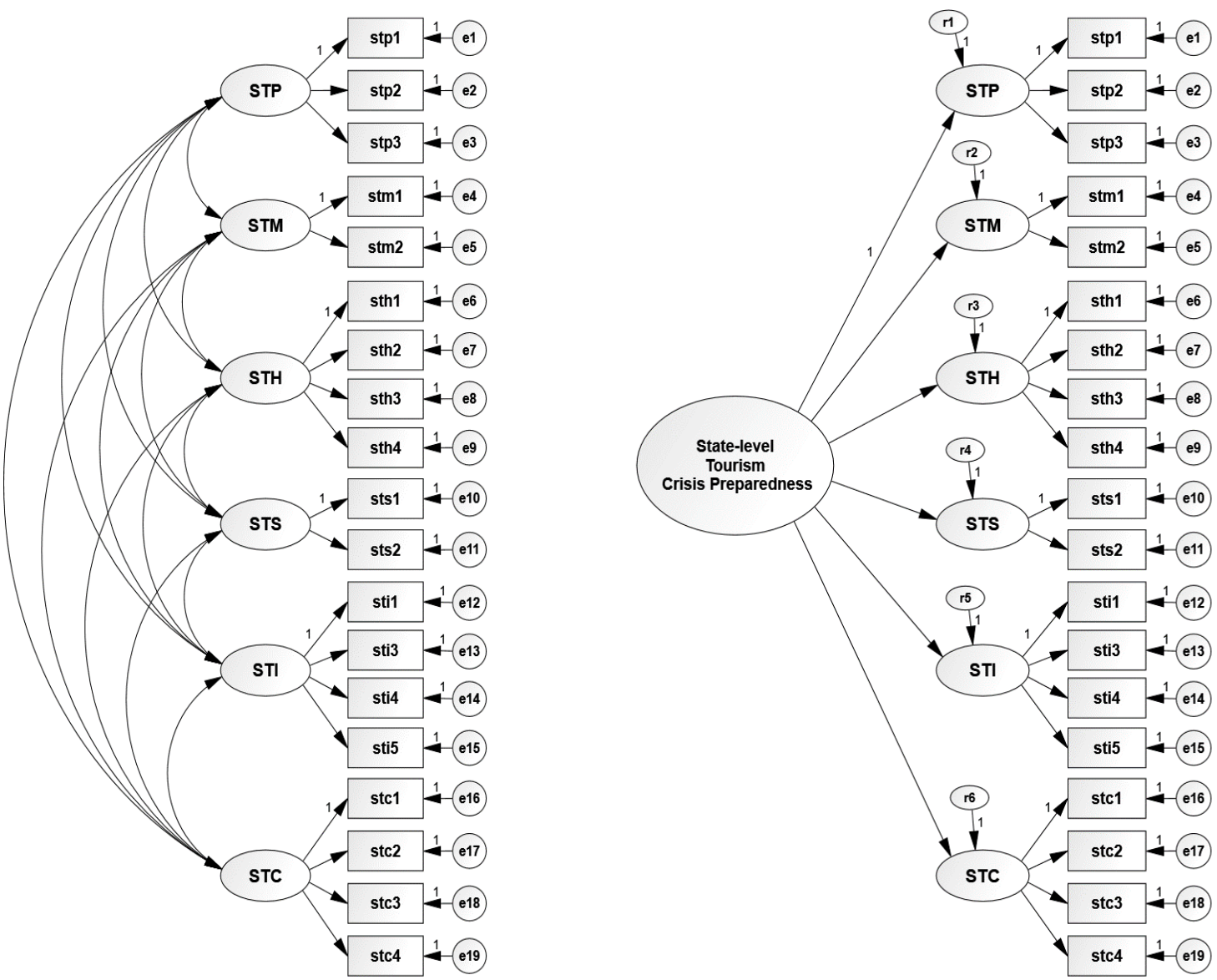


\section{Estimation}

After model identification, the parameters of the specified factor model are estimated using AMOS Graphics 23.0 in order to assure that the parameter estimates of the sample covariance matrix $S$ of the observed variables are as similar as possible to the model covariance matrix $\Sigma$ (Schumacker \& Lomax, 2004). Figure (5) and Tables (10) and (11) represent the state-level crisis-preparedness $1^{\text {st }}$ and 2 nd order-model's maximum likelihood estimates.
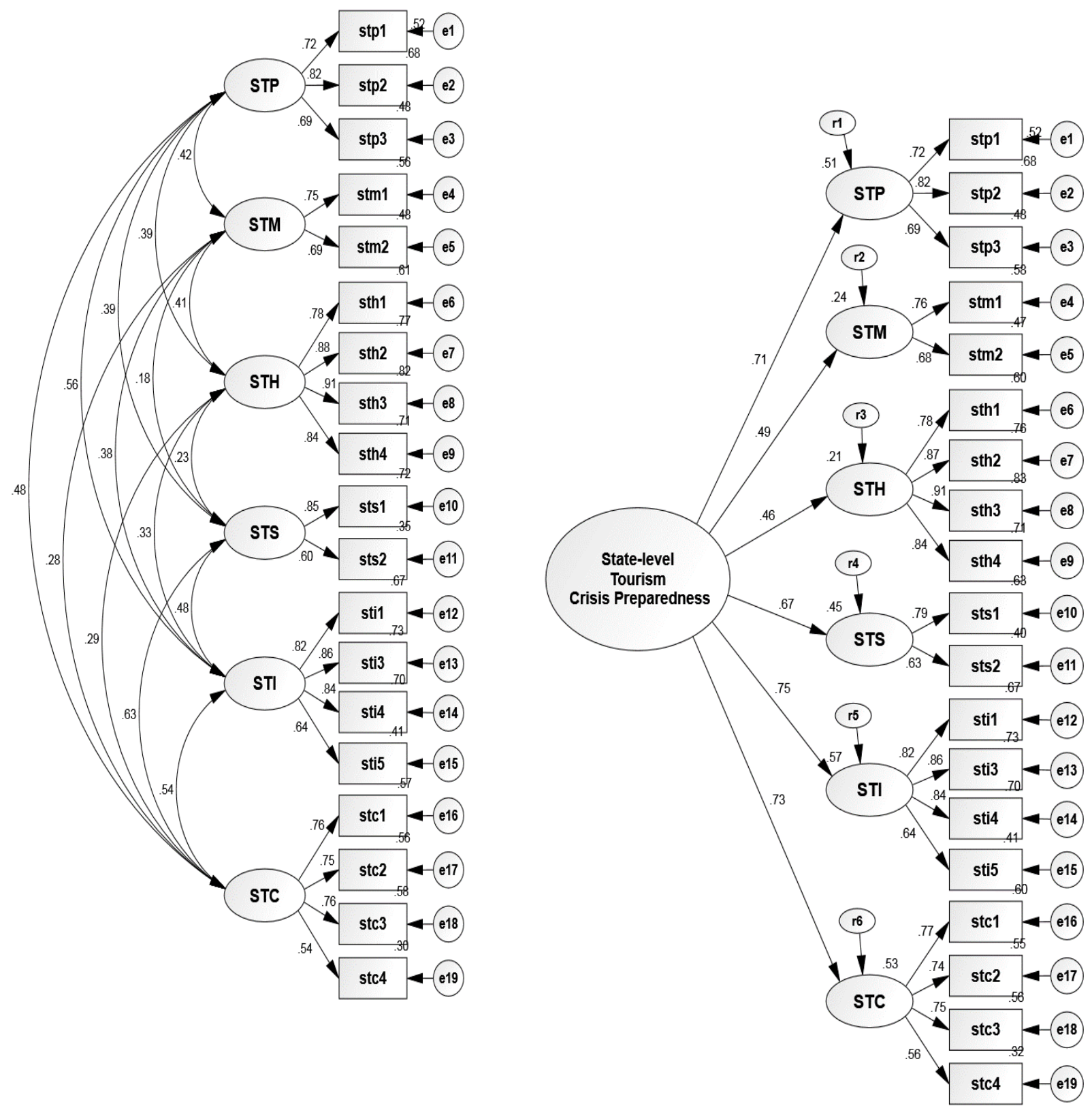

Figure (5): Factor loadings for the items of State-Level Crisis Preparedness $1^{\text {st }}$ and $2^{\text {nd }}$ order Models 
Table (10): State-Level Crisis-Preparedness 1st Order-Model's Maximum Likelihood Estimates

\begin{tabular}{|c|c|c|c|}
\hline \multicolumn{2}{|c|}{ Factor Loadings } & \multicolumn{2}{|l|}{ Correlations } \\
\hline STP $\rightarrow$ stp1 & .720 & STP $\leftrightarrow$ STM & .421 \\
\hline STP $\rightarrow$ stp2 & .824 & STM $\leftrightarrow$ STH & .407 \\
\hline STP $\rightarrow$ stp3 & .691 & STH $\leftrightarrow$ STS & .227 \\
\hline STM $\rightarrow$ stm1 & .749 & STS $\leftrightarrow$ STI & .485 \\
\hline $\mathrm{STM} \rightarrow \operatorname{stm} 2$ & .695 & STI $\leftrightarrow$ STC & .544 \\
\hline STH $\rightarrow$ sth1 & .779 & STP $\leftrightarrow$ STH & .394 \\
\hline STH $\rightarrow$ sth2 & .877 & STH $\leftrightarrow$ STI & .329 \\
\hline STH $\rightarrow$ sth3 & .906 & STS $\leftrightarrow$ STC & .633 \\
\hline STH $\rightarrow$ sth4 & .843 & STM $\leftrightarrow$ STC & .277 \\
\hline STS $\rightarrow$ sts1 & .846 & STP $\leftrightarrow$ STC & .481 \\
\hline STS $\rightarrow$ sts2 & .595 & STP $\leftrightarrow$ STS & .391 \\
\hline STI $\rightarrow$ sti1 & .821 & STP $\leftrightarrow$ STI & .557 \\
\hline STI $\rightarrow$ sti3 & .856 & STH $\leftrightarrow$ STC & .287 \\
\hline STI $\rightarrow$ sti4 & .839 & STM $\leftrightarrow$ STS & .181 \\
\hline STI $\rightarrow$ sti5 & .639 & STM $\leftrightarrow$ STI & .384 \\
\hline STC $\rightarrow$ stc1 & .758 & & \\
\hline $\mathrm{STC} \rightarrow$ stc2 & .751 & & \\
\hline $\mathrm{STC} \rightarrow \operatorname{stc3}$ & .759 & & \\
\hline $\mathrm{STC} \rightarrow \operatorname{stc} 4$ & .545 & & \\
\hline
\end{tabular}

Source: AMOS graphics output

Table (11): Factor Loadings of State-Level Crisis-Preparedness 2nd OrderModel

\begin{tabular}{|l|c|}
\hline State-Level Crisis-Preparedness $\rightarrow$ STP & .715 \\
\hline State-Level Crisis-Preparedness $\rightarrow$ STM & .495 \\
\hline State-Level Crisis-Preparedness $\rightarrow$ STH & .463 \\
\hline State-Level Crisis-Preparedness $\rightarrow$ STS & .671 \\
\hline State-Level Crisis-Preparedness $\rightarrow$ STI & .752 \\
\hline State-Level Crisis-Preparedness $\rightarrow$ STC & .729 \\
\hline
\end{tabular}

Source: AMOS graphics output 


\section{Evaluation}

\section{Unidimensionality}

Byrne (2016) states that unidimensionality is achieved if all measuring items possess acceptable factor loadings for their underlying latent constructs. In order to meet the condition of unidimensionality, any item with low factor loading should be eliminated. Awang (2015) argues that for newly developed measuring items factor loadings should at least be 0.5 By examining the factor loadings of the measuring items in tables (10) and (11), we can see that all the items have factor loadings of 0.5 or more. This implies that all the items meet the unidimensionality condition. Also, if we look at the factor loading of the $2^{\text {nd }}$ order CFM, we will find two factor loadings that can be problematic; state-level crisis-preparedness $\rightarrow$ STM $=.495$ and state-level crisis-preparedness $\rightarrow \mathrm{STH}=.463$. before taking a decision of eliminating any of those two constructs, fitness indices must first be examined.

\section{Validity \& Reliability}

Validity is defined as the instrument's ability to measure what is it supposed to measure (Awang, 2015). For each measurement model, two types of validity must be assured, convergent and discriminant validity. Convergent validity is accomplished when all the measuring items within a measurement model are statistically significant. Its achieved when all values of Average Variance Extracted (AVE) exceed 0.5 (ibid). discriminant validity means that the measurement model is free from redundant items. Its assured when the square root of AVE is greater than inter-construct correlations (ibid). Composite Reliability (CR) indicates the reliability and internal consistency of latent constructs (ibid). in order to achieve internal consistency, CR must be equal to or above 0.6 (ibid). 
For the 6 constructs of the State-level Crisis Preparedness confirmatory factor model, validity and reliability were assessed by calculating AVE, CR, and Discriminant validity index (see tables 12 and 13).

Table (12): The AVE and CR report of all constructs within the State-level Crisis Preparedness confirmatory factor model

\begin{tabular}{|c|c|c|}
\hline Construct & $\begin{array}{c}\text { CR } \\
\text { (Minimum 0.6) }\end{array}$ & $\begin{array}{c}\text { AVE } \\
\text { (Minimum 0.5) }\end{array}$ \\
\hline STM & $\mathbf{0 . 6 8 6}$ & $\mathbf{0 . 5 2 2}$ \\
\hline STP & $\mathbf{0 . 7 9 0}$ & $\mathbf{0 . 5 5 8}$ \\
\hline STH & $\mathbf{0 . 9 1 4}$ & $\mathbf{0 . 7 2 7}$ \\
\hline STS & $\mathbf{0 . 6 9 1}$ & $\mathbf{0 . 5 3 5}$ \\
\hline STI & $\mathbf{0 . 8 7 0}$ & $\mathbf{0 . 6 3 0}$ \\
\hline STC & $\mathbf{0 . 7 9 9}$ & $\mathbf{0 . 5 0 3}$ \\
\hline
\end{tabular}

$$
\begin{aligned}
& \mathrm{AVE}=\sum K^{2} / n \\
& \mathrm{CR}=\left(\sum K\right)^{2} /\left[\left(\sum K\right)^{2}+\right. \\
& \left.\left(\sum 1-K^{2}\right)\right]
\end{aligned}
$$

$K$ is the factor loading of every item

$n$ is the number of items in the model

By examining the above table, it can be noticed that $\mathrm{CR}$ for all constructs are within the accepted level $(\geq 0.6)$ which assures internal consistency of measuring items. Also, the AVE scores indicate that convergent validity is achieved.

Table (13): The discriminant Validity Index Summary for the State-level Crisis Preparedness confirmatory factor model

\begin{tabular}{|c|c|c|c|c|c|c|}
\hline Construct & STM & STP & STH & STS & STI & STC \\
\hline STM & $\mathbf{0 . 7 2 3}$ & & & & & \\
\hline STP & $\mathbf{0 . 4 2 1}$ & $\mathbf{0 . 7 4 7}$ & & & & \\
\hline STH & $\mathbf{0 . 4 0 7}$ & $\mathbf{0 . 3 9 4}$ & $\mathbf{0 . 8 5 3}$ & & & \\
\hline STS & $\mathbf{0 . 1 8 1}$ & $\mathbf{0 . 3 9 1}$ & $\mathbf{0 . 2 2 7}$ & $\mathbf{0 . 7 3 1}$ & & \\
\hline STI & $\mathbf{0 . 3 8 4}$ & $\mathbf{0 . 5 5 7}$ & $\mathbf{0 . 3 2 9}$ & $\mathbf{0 . 4 8 5}$ & $\mathbf{0 . 7 9 4}$ & \\
\hline STC & $\mathbf{0 . 2 7 7}$ & $\mathbf{0 . 4 8 1}$ & $\mathbf{0 . 2 8 7}$ & $\mathbf{0 . 6 3 3}$ & $\mathbf{0 . 5 4 4}$ & $\mathbf{0 . 7 0 9}$ \\
\hline
\end{tabular}

The bolded diagonal values represent the square root of AVE of each construct while the other values in the table are the correlations between the constructs. Discriminant validity is accomplished when the diagonal values ( $\sqrt{\text { AVE}})$ are higher than the other values in the table.

\section{Model Fit}

Anumber of model-fit indices is used to evaluate the hypothesized measurement model. Table (14) is a summary of used fit indices for this model testing. 
Table (14): Model testing of the State-level Crisis Preparedness confirmatory factor model

\begin{tabular}{|c|c|c|c|}
\hline $\begin{array}{c}\text { Name of } \\
\text { Category }\end{array}$ & $\begin{array}{c}\text { Index } \\
\text { Name }\end{array}$ & Result of Model Fit & $\begin{array}{c}\text { Assessment of } \\
\text { Model Fit }\end{array}$ \\
\hline \multirow{2}{*}{ Absolute Fit } & Chi-Square & $\chi^{{ }_{137}=\mathbf{2 1 2 . 9 4 1}(\mathbf{p}=\mathbf{. 0 0})}$ & Poor fit \\
\cline { 2 - 4 } & RMSEA & $\mathbf{. 0 5}$ & Good fit \\
\hline \multirow{3}{*}{ Incremental Fit } & IFI & .963 & Good fit \\
\cline { 2 - 4 } & TLI & .946 & Good fit \\
\cline { 2 - 4 } & CFI & .954 & Good fit \\
\hline Parsimonious Fit & Chisq/df & $\mathbf{1 . 6 3 3}$ & good fit \\
\hline
\end{tabular}

Source: AMOS output

As the table indicates, the Chi-square statistic equalled 212.941, with 137 degrees of freedom and $p$ value of .00 . The $\chi^{2}$ was significant, which implies that the specified confirmatory factor model was not supported by the sample variance-covariance data. However, Chi-Square is heavily affected by sample size. On the other hand, the root-mean-square error of approximation (RMSEA) was equal to .05, which was equalled the acceptable level of model fit. Similarly, the incremental fit index (IFI) index, the Tucker-Lewis index (TLI), and the Comparative fit index (CFI) were .96 and .94 and .95 . Finally, adjusted Chi-Square was 1.6 which was at an accepted level. According to these model fit indices, the fit of the initial confirmatory factor model for state-level crisis preparedness was good. Therefore, no model modification was required.

After the analysis was performed, the hypothesized model was accepted. State-level determinants were all accepted into the produced measurement model as they exhibited good fit indicators which indicate a high degree to which the sample data in $\mathbf{S}$ fit the theoretical model in $\Sigma$.

\section{Discussion}

One major finding in this study was that the state has a responsibility to enhance the level of crisis preparedness for tourism. This finding corroborates the ideas of Glaesser (2003), who argued that the government plays a very important role in orchestrating all other tourism stakeholders' 
efforts to increase preparedness through its policies and regulations. In the same vein, Christensen et al. (2016) state that crisis preparedness is a core government responsibility that is always very challenging to fulfill.

It is encouraging to compare the produced determinants of state-level crisis preparedness in this study with the results of other researches. Martens et al. (2016) emphasized the role of local community culture in creating a welcoming atmosphere for tourists which seems to be consistent with the produced determinant of "National Culture". Pennington et al (2011) highlighted the major role of the state in providing a clear, written and updated crisis plan for the tourism sector which also came consistent with the produced determinant "State Crisis Planning". The role of state-level crisis communication was also highly emphasized in literature (Avraham, 2015; Pennington et al., 2011; Martens et al., 2016). Lepp \& Gibson (2003) in their review of literature identified a number of factors that could be considered as risk factors to tourism, among the factors were terrorism and crime. Those two factors represented the determinant of "National Security" for this current study. The reason for that was during the qualitative data collection and analysis, the participants emphasized the important role of the state in providing an atmosphere of safety where touristic activities can thrive. In order to give a label for that meaning, the researcher reviewed the definition of "National Security" and found that one of its definitions is "the safety of a nation against threats such as terrorism, war, or crime" (https://www.lexico.com, 2019).

One State-level determinant was "State Habilitation". This construct denoted the degree to which the involved state formal authorities are keen on hiring qualified individuals in the tourism sector. This finding is supported by the results of Abdelrahman (2017) in her investigation of the impact of political crisis on tourism. She argued that one of the main reasons of the Egyptian-tourism vulnerability to political crises was the absence of specialized and trained people to deal with such incidents. 


\section{References}

Abdelrahman, R., 2017. Managing Political Crisis and its impact on Tourism: The Case of January 25th Revolution in Egypt. Journal of Association of Arab Universities for Tourism \& Hospitality, 14(2), pp.79-92.

AFP.com. 2014. Plateforme De L'Info. [online] Available at: $<$ https://www.afp.com/>

Avraham, E., 2015. Destination image repair during crisis: Attracting Tourism During the Arab Spring uprisings. Tourism Management, 47, pp.224-232.

Awang, Z., 2015. SEM Made Simple: A Gentle Approach to Learning Structural Equation Modeling. NPWS Rich Publication.

Bailey, K., 1978. Methods in Social Research. New York: Free Press.

Barton, L., 1993. Crisis in Organizations. Cincinnati, Ohio: College Division/South-Western Publishing Co.

Baxter, E. and Bowen, D., 2004. Anatomy of tourism crisis: explaining the effects on tourism of the UK foot and mouth disease epidemics of 1967-68 and 2001 with special reference to media portrayal. International Journal of Tourism Research, 6(4), pp.263-273.

Boin, A. and Lagadec, P., 2000. Preparing for the Future: Critical Challenges in Crisis Management. Journal of Contingencies and Crisis Management, 8(4), pp.185-191.

Boin, A., Kuipers, S. and Overdijk, W., 2013. Leadership in Times of Crisis: A Framework for Assessment. International Review of Public Administration, 18(1), pp.79-91.

Burrell, S. and Heiselt, A., 2012. Presidential Perspectives of Crisis Preparedness at Christian Higher Education Institutions. Christian Higher Education, 11(4), pp.260-271.

Capmas.gov.eg. 2019. Central Agency for Public Mobilization and Statistics. [online] Available at: 〈https://www.capmas.gov.eg>. 
Carlsen, J. and Liburd, J., 2008. Developing a Research Agenda for Tourism Crisis Management, Market Recovery and Communications. Journal of Travel \& Tourism Marketing, 23(2-4), pp.265-276.

Cbe.org.eg. 2019. Central Bank of Egypt. [online] Available at: <https://www.cbe.org.eg>.

Cdws.travel. 2020. Egyptian Chamber of Diving and Water Sports. [online] Available at: https://www.cdws.travel/.

Charmaz, K., 2006. Constructing Grounded Theory: A Practical Guide Through Qualitative Analysis. London: Sage.

Christensen, T., Laegreid, P. and Rykkja, L., 2016. Organizing for Crisis Management: Building Governance Capacity and Legitimacy. Public Administration Review, 76(6), pp.887-897.

Coombs, W., 2018. Ongoing Crisis Communication. 4th ed. SAGE Publications, Inc.

Crandall, W., Parnell, J. and Spillan, J., 2014. Crisis Management. Thousand Oaks (Calif.): SAGE.

Creswell, J. and Plano Clark, V., 2018. Designing and Conducting Mixed Methods Research. 3rd ed. London: SAGE Publications, Inc.

Creswell, J. and Poth, C., 2018. Qualitative Inquiry \& Research Design. London: SAGE Publications.

Cte-egypt.org. 2020. Egyptian Chamber of Tourist Establishments. [online] Available at: <http://cte-egypt.org/?lang=en>

Cumming, R., 1990. Is probability sampling always better? A comparison of results from a quota and a probability sample survey. Community Health Studies, 14(2), pp.132-137.

Daily News Egypt. 2019. Daily News Egypt - Latest Financial, Business, And Political News. [online] Available at: <https://wwww.dailynewssegypt.com/>. Denzin, N., 2012. Triangulation 2.0. Journal of mixed methods research, 6(2), pp.80-88.

DeVellis, R., 2017. Scale Development. Los Angeles: SAGE.

Dey, I., 1993. Qualitative Data Analysis: A user friendly guide for social scientists. Routledge. 
Editorial, R., 2019. Breaking News, Business News, Financial and Investing News \& More | Reuters.Co.Uk. [online] U.K. Available at: <https://www.reuters.com>.

Egypt.travel. 2019. Egyptian Tourism Authority. [online] Available at: <http://www.egypt.travel/>

Egyptianctc.com. 2020. Egyptian Chamber of Tourist Commodities. [online] Available at: <http://www.egyptianctc.com/>

Elsubbaugh, S., Fildes, R. and Rose, M., 2004. Preparation for Crisis Management: A Proposed Model and Empirical Evidence. Journal of Contingencies and Crisis Management, 12(3), pp.112-127.

Eriksson, PhD, K., 2016. Framework for crisis preparedness planning: Four required areas for developing a learning process. Journal of Emergency Management, 13(6), p.519.

Etaa-egypt.org. 2020. Egyptian Travel Agents Associations. [online] Available at: <https://www.etaa-egypt.org/DefaultNewEn.aspx> [Accessed 2 June 2020].

Etikan, I. and Bala, K., 2017. Sampling and Sampling Methods. Biometrics \& Biostatistics International Journal, 5(6), p.00149.

Faulkner, B., 2001. Towards a framework for tourism disaster management. Tourism Management, 22(2), pp.135-147.

Fetters, M., Curry, L. and Creswell, J., 2013. Achieving Integration in Mixed Methods Designs-Principles and Practices. Health Services Research, 48(6pt2), pp.2134-2156.

Field, A., 2018. Discovering Statistics. London: Sage Publications Ltd.

Fowler, K., Kling, N. and Larson, M., 2007. Organizational Preparedness for Coping with a Major Crisis or Disaster. Business \& Society, 46(1), pp.88-103. Fuller, W., 2011. Sampling Statistics. John Wiley \& Sons.

Gaafar, H., 2013. Tourism Crisis Management in the light of Political Unrest in Egypt. Journal of Faculty of Tourism and Hotels, Fayoum University, 7(2), pp.26-43.

Gate.ahram.org.eg. 2011, 2012, 2015. [online] Available at: <http://gate.ahram.org.eg/> 
Glaesser, D., 2006. Crisis Management in The Tourism Industry. Boston: Butterworth-Heinemann.

Greene, J., Caracelli, V. and Graham, W., 1989. Toward a Conceptual Framework for Mixed-Method Evaluation Designs. Educational Evaluation and Policy Analysis, 11(3), pp.255-274.

Harb, N., 2013. Tourism Crisis Management Strategies: the case of travel agencies in Egypt. Journal of Faculty of Tourism and Hotels, Fayoum University, 7(2), pp.12-25.

Israel, G., 1992. Determining sample size [Fact Sheet] PEOD-6. Florida Cooperative Extension Service, university of Florida, [online] Available at: <http://edis.ifas.ufl.edu/scripts/htmlgen.exe?>

Johnson, R., Onwuegbuzie, A. and Turner, L., 2007. Toward a Definition of Mixed Methods Research. Journal of Mixed Methods Research, 1(2), pp.112133.

Kaplan, D., 2009. Structural Equation Modeling. Los Angeles: Sage.

Karagiannis, A., Maditinos, Z. and Vassiliadis, C., 2006. organizational preparation for crises and disasters in the tourism sector: perceptions and planning of tourist businesses in northern Greece. In: 24th EuroCHRIE Congress, Thessaloniki.

Kash, T. and Darling, J., 1998. Crisis management: prevention, diagnosis and intervention. Leadership \& Organization Development Journal, 19(4), pp.179-186.

Keown- McMullan, C., 1997. Crisis: when does a molehill become a mountain? Disaster Prevention and Management: An International Journal, 6(1), pp.4-10.

Kovoor-Misara, S., 1996. Moving toward crisis preparedness: Factors that motivate organizations. Technological Forecasting and Social Change, 53(2), pp.169-183.

Kovoor-Misra, S., 1995. A multidimensional approach to crisis preparation for technical organizations: Some critical factors. Technological Forecasting and Social Change, 48(2), pp.143-160. 
Kovoor-Misra, S., 2019. Crisis Management. 1st ed. [Place of publication not identified]: SAGE Publications.

Kovoor-Misra, S., Zammuto, R. and Mitroff, I., 2000. Crisis Preparation in Organizations. Technological Forecasting and Social Change, 63(1), pp.43-62. Krosnick, A. and Presser, S., 2020. Handbook of Survey Research, Chapter 9. In: Marsden and Wright Editors, ed.

Laws, E. and Prideaux, B., 2005. Crisis Management: A Suggested Typology. Journal of Travel \& Tourism Marketing, 19(2-3), pp.1-8.

Lepp, A. and Gibson, H., 2003. Tourist roles, perceived risk and international tourism. Annals of Tourism Research, 30(3), pp.606-624.

Lexico Dictionaries | English. 2019. Definitions, Meanings, Synonyms, And Grammar by Oxford Dictionary On Lexico.Com. [online] Available at: <https://www.lexico.com/>

Maditinos, Z. and Vassiliadis, C., 2008. Crises and disasters in tourism industry: happen locally, affect globally. In: Management of international business and economics systems, MIBES conference. pp.67-76.

Maléřová, L., Adamec, V., Vicente, R. and Brumar, J., 2018. Assessment of Crisis Preparedness Resourcing to Stress Tests. TRANSACTIONS of the VŠB - Technical University of Ostrava, Safety Engineering Series, 13(1), pp.8-14.

Martens, H., Feldesz, K. and Merten, P., 2016. Crisis Management in Tourism - A Literature Based Approach on the Proactive Prediction of a Crisis and the Implementation of Prevention Measures. Athens Journal of Tourism, 3(2), pp.89-101.

McConnell, A. and Drennan, L., 2006. Mission Impossible? Planning and Preparing for Crisis1. Journal of Contingencies and Crisis Management, 14(2), pp.59-70.

Mitroff, I. and Anagnos, G., 2001. Managing Crises Before They Happen. New York: AMACOM.

Mitroff, I., 2004. Crisis Leadership. Hoboken, N.J.: Wiley. 
Pearson, C. and Mitroff, I., 1993. From crisis prone to crisis prepared: a framework for crisis management. Academy of Management Perspectives, 7(1), pp.48-59.

Pelfrey, W., 1998. Tourism and crime: A preliminary assessment of the relationship of crime to the number of visitors at selected sites. International Journal of Comparative and Applied Criminal Justice, 22(2), pp.293-304.

Pelfrey, W., 2005. The Cycle of Preparedness: Establishing a Framework to Prepare for Terrorist Threats. Journal of Homeland Security and Emergency Management, 2(1).

Pennington-Gray, L., Thapa, B., Kaplanidou, K., Cahyanto, I. and McLaughlin, E., 2011. Crisis Planning and Preparedness in the United States Tourism Industry. Cornell Hospitality Quarterly, 52(3), pp.312-320.

Prideaux, B., Laws, E. and Faulkner, B., 2003. Events in Indonesia: exploring the limits to formal tourism trends forecasting methods in complex crisis situations. Tourism Management, 24(4), pp.475-487.

Racherla, P. and Hu, C., 2009. A Framework for Knowledge-Based Crisis Management in the Hospitality and Tourism Industry. Cornell Hospitality Quarterly, 50(4), pp.561-577.

Ritchie, B., 2004. Chaos, crises and disasters: a strategic approach to crisis management in the tourism industry. Tourism Management, 25(6), pp.669683.

Ritchie, B., Bentley, G., Koruth, T. and Wang, J., 2011. Proactive Crisis Planning: Lessons for the Accommodation Industry. Scandinavian Journal of Hospitality and Tourism, 11(3), pp.367-386.

Ritchie, B., Mair, J. and Walters, G., 2014. Tourism Crises and disasters moving the research agenda forward. In: The Wiley Blackwell Companion to Tourism, 1st ed. John Wiley \& Sons, Ltd., pp.611-622.

Sabri, H., 2013. The Role of Corporate Culture in Maintaining Organizational Operations during the Global Financial Crisis. Journal of Social and Development Sciences, 4(3), pp.141-146.

Seymour, M. and Moore, S., 2000. Effective Crisis Management: Worldwide Principles and Practice. London: Continuum. 
Sheaffer, Z. and Mano-Negrin, R., 2003. Executives' Orientations as Indicators of Crisis Management Policies and Practices*. Journal of Management Studies, 40(2), pp.573-606.

Sönmez, S., Apostolopoulos, Y. and Tarlow, P., 1999. Tourism in Crisis: Managing the Effects of Terrorism. Journal of Travel Research, 38(1), pp.1318.

Strauss, A. and Corbin, J., 1998. Grounded Theory in Practice. Sage.

Sustainabledevelopment.un.org. 2019. Sustainable Development Knowledge Platform. [online] Available at: <https://sustainabledevelopment.un.org/> .

Tashakkori, A. and Creswell, J., 2007. Editorial: The New Era of Mixed Methods. Journal of Mixed Methods Research, 1(1), pp.3-7.

Tashakkori, A. and Teddlie, C., 1998. Mixed Methodology. Thousand Oaks [etc]: Sage.

Tashakkori, A. and Teddlie, C., 2010. Sage Handbook of Mixed Methods in Social \& Behavioral Research. Sage.

Tda.gov.eg. 2019. Tourism Development Authority. [online] Available at: http://www.tda.gov.eg/MainPages/HomeEn.aspx.

Thomas, R., 2011. Blending Qualitative \& Quantitative Research Methods in Theses and Dissertations. Thousand Oaks, Calif.: SAGE [distributor].

Turner, R., 2018. Travel and Tourism Economic Impact 2018 Egypt. [online] Available at: https://www.wttc.org/economic-impact/countryanalysis/country-data/.

UNWTO e-Library. 2020. UNWTO E-library. [online] Available at: https://www.e-unwto.org/

Volo, S., 2008. Communicating Tourism Crises Through Destination Websites. Journal of Travel \& Tourism Marketing, 23(2-4), pp.83-93.

Wang, J. and Ritchie, B., 2013. Attitudes and perceptions of crisis planning among accommodation managers: Results from an Australian study. Safety Science, 52, pp.81-91.

World Bank. 2019. World Bank Group - International Development, Poverty, \& Sustainability. [online] Available at: <https://www.worldbank.org/>. WTTC. 2017. Home. [online] Available at: <https://www.wttc.org/>. 